Article

\title{
Raman Spectroscopic Analysis of an Early 20th Century English Painted Organ Case by Temple Moore
}

\author{
Christopher Brooke ${ }^{1, *,+}\left(\mathbb{D}\right.$, Howell Edwards ${ }^{2,+}$ (D) , Peter Vandenabeele ${ }^{3}$, Sylvia Lycke ${ }^{3}(\mathbb{C}$ \\ and Michelle Pepper ${ }^{4}$ \\ 1 Department of History, University of Nottingham, University Park, Nottingham NG7 2RD, UK \\ 2 School of Chemistry \& Biosciences, Faculty of Life Sciences, University of Bradford, Bradford BD7 1DP, UK; \\ h.g.m.edwards@bradford.ac.uk \\ 3 Department of Archaeology, University of Ghent, Sint Pietersnieuwstraat 35, B-9000 Ghent, Belgium; \\ Peter.Vandenabeele@UGent.be (P.V.); sylvia.lycke@ugent.be (S.L.) \\ 4 Independent Conservator; minpepper@yahoo.com \\ * Correspondence: chris.brooke@nottingham.ac.uk \\ + These authors contributed equally to this work.
}

Received: 25 September 2020; Accepted: 19 October 2020; Published: 21 October 2020

check for updates

\begin{abstract}
An organ case from Lincoln, England, designed by the architect Temple Moore in 1907 was examined during conservation work using Raman spectroscopy in order to analyze the decorative paint composition. Samples from the six principal colours were extracted and examined using a Bruker Senterra R200-L spectrometer. The results are the first known formal analysis of a painted scheme by this architect, and they reveal a mixture of commonly used pigments for the period and the unexpected use of simpler, earth pigments, along with an unusual admixture in the red, along with an organic additive. The findings are of importance to both the conservation of Temple Moore's artwork, in understanding the experimentation used in early twentieth-century England, and in furthering our knowledge of ecclesiastical decorative artwork of the late nineteenth and early twentieth centuries.
\end{abstract}

Keywords: Raman spectroscopy; paint; pigments; artwork; twentieth century; arts and crafts; Temple Moore; analysis

\section{Introduction}

In 1906 the Gothic Revival architect Temple Lushington Moore was commissioned to construct the chapel of the Bishop's Hostel in Lincoln, England, by Canon John du Buisson, who paid for the work in its entirety in the sum of $£ 4640$ [1] (p. 248). Moore built the chapel in the former County Hospital of 1776-1777 designed by John Carr as part of the work to complement the new Lincoln Theological College (Scholae Cancellarii) which had been created in 1874, and work was completed in 1907 [2] (p. 510). The interior contained a wooden west screen, gallery, and an organ case (Figure 1), all created by Moore in typical Gothic Revival manner, and it is known that he took a particular interest in the design of organs and their cases, working widely with Arthur Hill, who was associated with Will Hill and Son, organ builders [3]. The contractor is known to have been Fisher Brothers of Mansfield, Nottinghamshire, and the "decoration" was by John Thomas of York, but although it is unclear what was meant by "decoration" in the documents it almost certainly refers to the physical painting of the interior, including the organ case, to Moore's designs [4] (p. 202). 


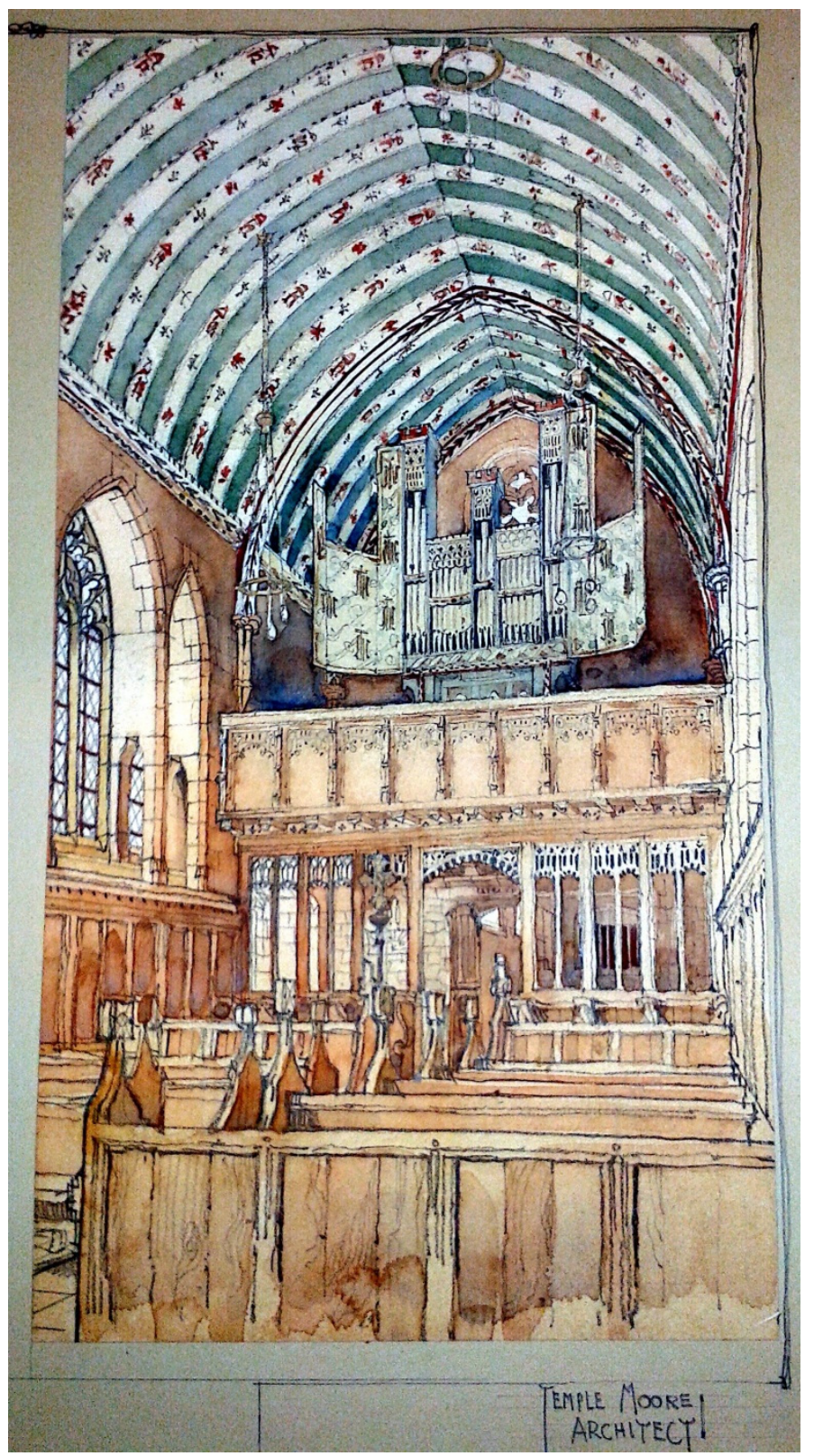

Figure 1. A drawing by the architect Temple Moore showing the design of the interior west end of the Lincoln Theological College in 1907 with the organ case in its original position and painted.

The name of the original organ maker is unknown. In 1935 a replacement organ mechanism by Cousans of Lincoln was installed, which retained the original 1907 Temple Moore case. In 1995 the Lincoln Theological College closed and the building was taken over by de Montfort University, which renamed it "Chad Varah House" and used it for several years as its Faculty of Art and Design until it left in 2009. It then became the Lincoln School of Theology for a short period before becoming redundant, although it was retained as it is a listed building and therefore protected. It was sold to developers in 2016. At the same time the parish church of St Wilfrid at Kelham in Nottinghamshire was seeking a new organ as its existing instrument had become uneconomic to repair, and shortly after the former Lincoln Theological College was sold it purchased the organ complete with original case; it was removed and transported to Kelham in early 2017.

The organ and case were placed in the south aisle of Kelham St Wilfrid [5] and in 2018 work commenced on the restoration and conservation of both the instrument and the case, the former by Henry Groves and Son Ltd, organ builders, of Nottingham, U.K., and the conservation of the case 
by Michelle Pepper, conservator, of Newark on Trent, U.K. During the initial assessment phase of conservation it was apparent that the painted decoration was unusually powdery and appeared poorly bound to the wooden substrate. Laboratory testing, using Biuret reagent (a standard colorimetric technique for the identification of proteins using a reagent made by dissolving $2.5 \mathrm{~g}$ of copper (II) sulfate and $6 \mathrm{~g}$ of sodium potassium tartrate tetrahydrate in a $3 \%$ solution of sodium hydroxide) [6] was undertaken to ascertain if the binder was proteinaceous, but the results were negative indicating that the decoration was probably not based on glue-bound distemper as might be expected at the period of execution $[7,8]$, unless aging deterioration has proceeded to the point where no trace of protein remains. As animal glues are prone to degradation in this manner, this may be the logical explanation. The decoration of the two large side doors was particularly unstable and the only viable cleaning method was determined to be the use of dry artists' rubbers (dry, conservation grade, erasers and eraser crumbs are a common surface cleaning material employed in paper conservation, and the technique is also sometimes appropriate for use on other sensitive painted surfaces) [9]. Following cleaning, an isolating consolidation layer of Paraloid (Acryloid) B72, a copolymer of ethyl methacrylate and methyl acrylate, was applied and some minor retouching of missing detail undertaken using watercolours. The gold paint on the organ pipes, probably applied in 1935, was not analyzed as it was clearly not part of Moore's original scheme which would almost certainly have comprised gilding [10]. The paint had oxidized and was unsightly, therefore the decision was made to remove it and not to repaint.

The decoration comprises stylized foliate and geometric patterns with borders. The cream and green side panels are interspersed with the sacred Christian monogram IHS (Figure 2). Much of the work appears to be stenciled although some has clearly been executed freestyle and is typical of Moore's other work, for example, the reredos at Middlesborough St Columba and the organ case at Radwinter St Mary the Virgin, both in England. The pipe canopies are ornately constructed in Gothic Revival style with quatrefoils and tracery, capped by dentil courses. Some sections of the case have been overpainted, possibly as a result of the original pigment being accidentally removed, perhaps by washing. The overpaint is in an oil-based media and suggests either repainting or amalgamation of parts from another case at some period, most probably from 1935 when the replacement organ was installed.

Colours comprise dark red, dark and light greens, blue, cream, and some black. As many areas were friable before conservation, the opportunity was taken to extract small samples from the original paint scheme for Raman spectroscopic analysis, as Temple Moore's work, while widely known and catalogued $[11,12]$ is poorly understood in scientific terms and no previous work is known on the analysis of his chosen decorative colour schemes.

One of the principal objectives of this project has been to further our knowledge of ecclesiastical artwork undertaken in the United Kingdom by a group of prolific architects of the late Victorian and Edwardian era, approximately between the years 1860 and 1910 [13]. This type of decorative artwork, typically applied to church interiors in the form of painted screens, reredoses, dado rails, organ cases, pulpits, and the interior of roofs, has had little published scientific analysis and what has been done tends to be on earlier objects [14,15], unlike wall paintings of all periods that have been the subject of extensive research [16-18]. Major architects engaged on ecclesiastical projects such as Sir Arthur Blomfield, Sir Ninian Comper [19], William Butterfield [20], Sir George Gilbert Scott and sons George and Oldrid, George Frederick Bodley [21], Norman Shaw, Temple Moore, Ewan Christian, William Burges [22], William Caröe, Sir Edwin Lutyens [23], and many others, commissioned a vast amount of such decorative church artwork which is well known for its form and style but very poorly understood in terms of pigment and binder composition, these details usually only coming to light when conservation work is undertaken or to inform conservation, and rarely openly published as individual studies [24-26]. Although the analysis in this study has arisen because the organ case involved required conservation, the opportunity has been taken to further our technical knowledge of commissioned artwork of the period. 


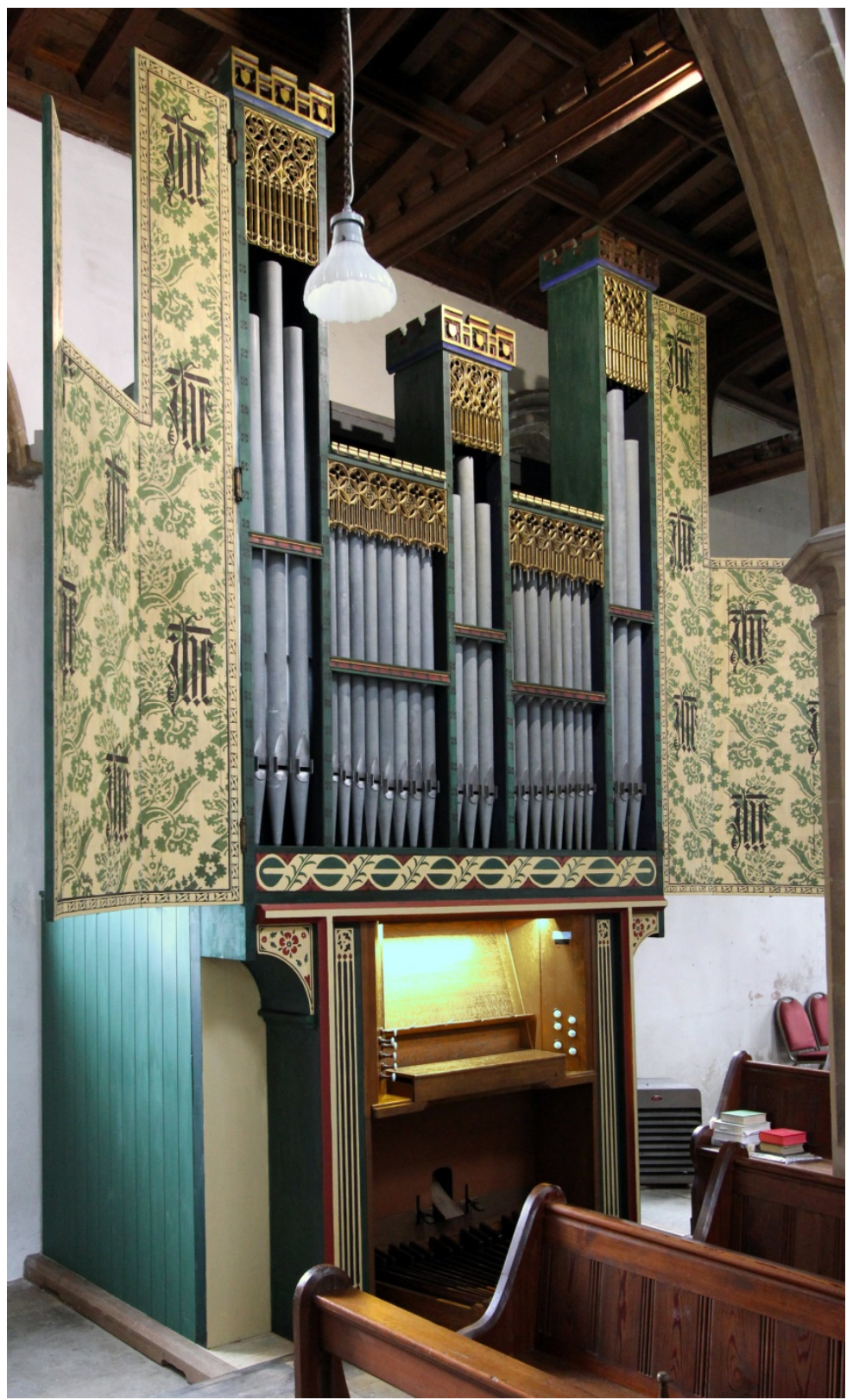

Figure 2. The organ case in its current position in Kelham church, England, following conservation.

Temple Moore (1856-1920) was without question among the greatest British ecclesiastical architects of his period, undertaking more than 150 major projects between 1878 and 1918. Yet the craftsmen and craftswomen who worked for him, and for his peers, are little known or understood and their work and methods are fully deserving of detailed analytical study.

\section{Materials and Methods}

Paint samples were taken from the organ case only where paint loss was deemed inevitable due to the loose condition and complete breakdown of the original binding. No sound areas of paint were sampled nor any of the areas of overpaint which are clearly not part of the original scheme. Small samples were extracted from all areas of differing colour using a scalpel, bagged and sealed, and sent to the Raman Spectroscopy Research Group at Ghent University for analysis. The sampling scheme, as dictated by paint condition, is shown in Figure 3. 


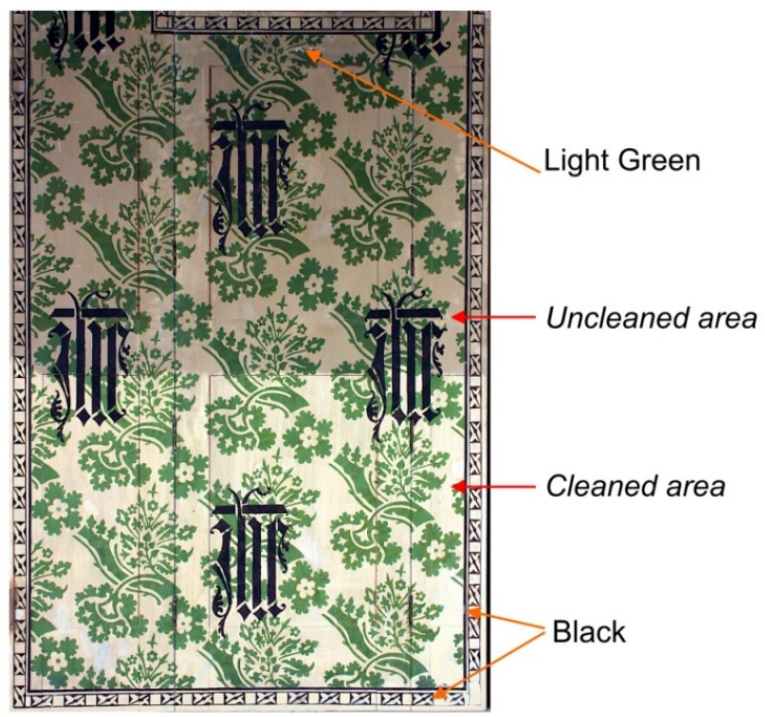

(a)

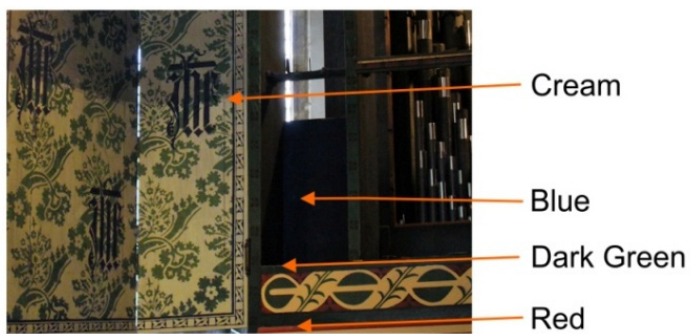

(b)

Figure 3. Sampling scheme for pigment extraction from areas already damaged and which had loose and detaching paint: (a) right-hand panel; (b) lower left-hand panel and console.

Raman spectroscopy is now a well established analytical technique for the characterization of pigments and their substrates on frescoes, paintings, and on decorated artefacts comprising a range of materials, including wood, ceramics, and metals [27-33]. Even in complex mixtures the key spectral band signatures can be identified and correlated with the use of particular pigments either alone or in admixture [34,35] (Table 1).

Here, Raman spectra were obtained using a Bruker Senterra R200-L spectrometer operating with two laser excitation wavelengths, namely $532 \mathrm{~nm}$ (Nd/YAG laser frequency doubled) in the green region of the electromagnetic spectrum and a $785 \mathrm{~nm}$ diode laser in the near infrared region with a thermoelectrically cooled $(1024 \times 556$ pixel resolution $)$ CCD detector. The latter excitation wavelength is particularly useful when evidence of fluorescence emission is observed in specimens using visible wavelength excitation, as a result of degraded varnish or surface coatings on paintings. The spectral data were acquired from an Olympus Raman microscope attachment with $5 \times, 20 \times$, and 50× objective lens magnification, representing a sample interrogation footprint of approximately 2 microns diameter for the 50× magnification objective lens. Spectral accumulation of up to 10 scans per sampling point enabled a preferential signal-to-noise ratio to be established with a spectral resolution of $10 \mathrm{~cm}^{-1}$ or better and replicate sampling was undertaken for each specimen submitted for analysis to verify the presence of pigment particles in admixture.

The extensive databases in the literature that are relevant to the Raman spectroscopic interpretation of spectral data from pigments and their substrates in artworks are mainly derived from early historiated manuscripts and prehistoric rock art, and comprise natural minerals and their synthetic derivatives 
and replacements which were used in later painted artworks [36-45]. Here, the spectral data and characteristic Raman spectral bands have been identified in degraded specimens which provide an unequivocal interpretation of the composition of natural and synthetic pigments, alone or in admixture, and can be correlated with the literature which describes standards and spectra derived from better preserved samples of artworks. The fact that the organ case in this study was in need of restoration is witness to the degradation suffered by the artwork over time and this is the reason that the Raman spectra display emission backgrounds and features are perhaps not as clearly defined as would have been expected from their pure mineral congeners.

Table 1. Raman spectral wavenumbers $/ \mathrm{cm}^{-1}$ of mineral and synthetic pigments used in the Temple Moore organ case decoration (see references [35], and [38-43]).

\begin{tabular}{|c|c|c|c|}
\hline Pigment & Formulation & Alternative Name & Wavenumbers $/ \mathrm{cm}^{-1} *$ \\
\hline Chrome yellow & $\mathrm{PbCrO}_{4}$ & lead (II) chromate, crocoite & $134,325,347,358,376,840$ \\
\hline Hematite & $\mathrm{Fe}_{2} \mathrm{O}_{3}$ & iron (III) oxide & $224,245,291,411,500,611,1320$ \\
\hline Red lead & $\mathrm{Pb}_{3} \mathrm{O}_{4}$ & lead(II) lead (IV) tetroxide & $121,152,223,232,313,391,477,549$ \\
\hline Calcite & $\mathrm{CaCO}_{3}$ & calcium carbonate, limestone, chalk & $151, \mathbf{2 7 3}, \mathbf{7 1 2}, 1086$ \\
\hline Gypsum & $\mathrm{CaSO}_{4} \cdot 2 \mathrm{H}_{2} \mathrm{O}$ & calcium sulfate dihydrate & $210,412,481,617,668,1007,1136,3407$ \\
\hline Prussian blue & $\mathrm{Fe}_{4}\left[\mathrm{Fe}(\mathrm{CN})_{6}\right]_{3}$ & ferric hexacyanoferrate, Berlin/Paris blue & $275,507,2155$ \\
\hline Bone black & $\mathrm{C}$ & ivory black & $461,643,960,1320,1580$ \\
\hline
\end{tabular}

* Distinctive wavenumbers highlighted in bold script.

It is a common misconception that the use of infrared is better for organics than Raman, but in fact Raman can be quite definitive regarding resins and gums, especially when these are in admixture with cellulosic materials and aqueous extracts where the broad and intense $\mathrm{OH}$ group absorptions, and their associated hydrogen-bonding broadening, often cause the masking or obscuration of features in the infrared from other entities. This does not occur in the Raman, where the scattering factor for $\mathrm{OH}$ groups is smaller. In particular the presence of very strong and polar carbonyl groups in organic moieties is easily detected in the infrared but the intense features generally cause problems in identifying other organic vibrations in their vicinity such as unsaturated carbon-carbon and carbon-nitrogen bonds $[46,47]$.

The combination of molecular spectroscopic and elemental analytical techniques is an approach that has been adopted for complex specimens hitherto [48] and has some advantages, particularly for in situ measurements using XRF spectrometry. In this project, access to elemental techniques analysis was not available but we do not foresee that any additional information of note would have been forthcoming.

As stated in the previous section, it is not possible to effect a direct comparison with pigments from other Temple Moore decorative artwork as this is the first time his palette has been characterized analytically.

\section{Results}

The specimens and their identified pigments from their Raman spectral bands are listed below.

Red: chrome yellow, hematite, red lead, calcite, and gypsum. Evidence of a binder or varnish is indicated by features at 1617, 1592, 1483, 1466, 1424, 1330, 1259, 1226, 1208, 1168, and $1001 \mathrm{~cm}^{-1}$, which can be assigned to an aromatic resin, such as dammar or pine resin (Figure 4). 


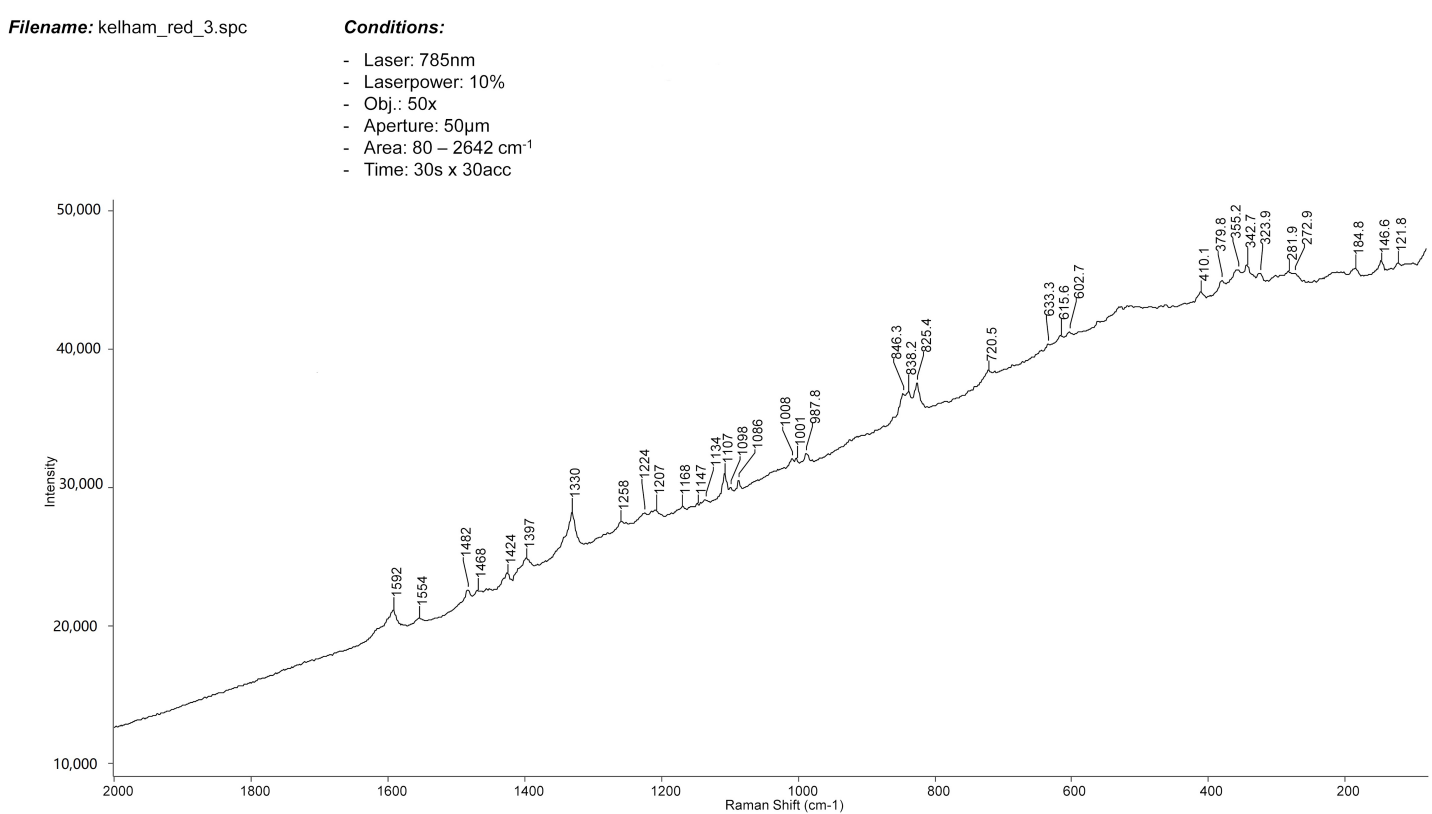

Figure 4. Raman spectrum of red pigment, $785 \mathrm{~nm}$ excitation, showing chrome yellow, hematite, red lead, and organic resin.

Blue: Prussian blue, calcite, and anhydrite (Figure 5).

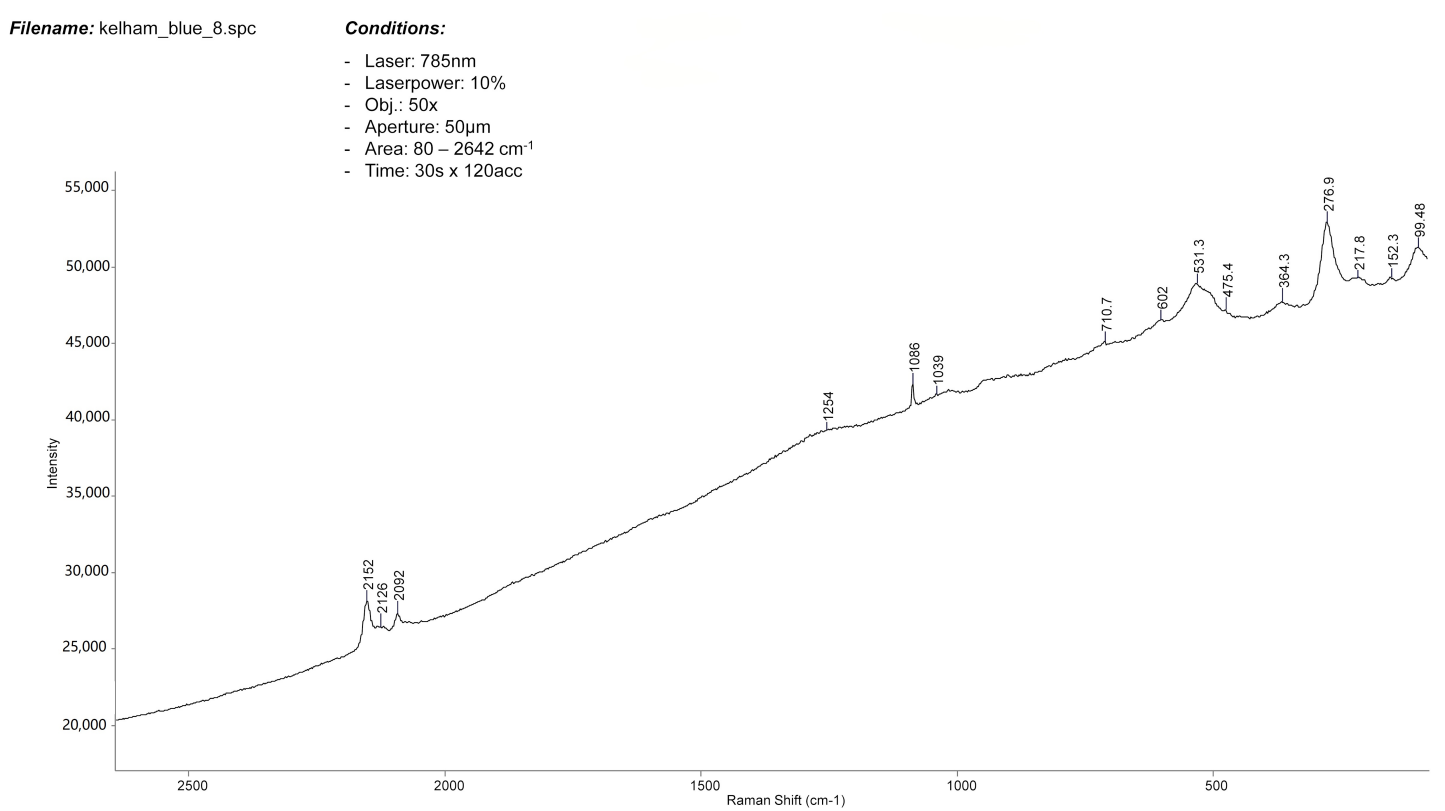

Figure 5. Raman spectrum of blue pigment, $785 \mathrm{~nm}$ excitation, showing Prussian blue.

Dark green: Prussian blue, chrome yellow, calcite, and carbon black (Figure 6). 


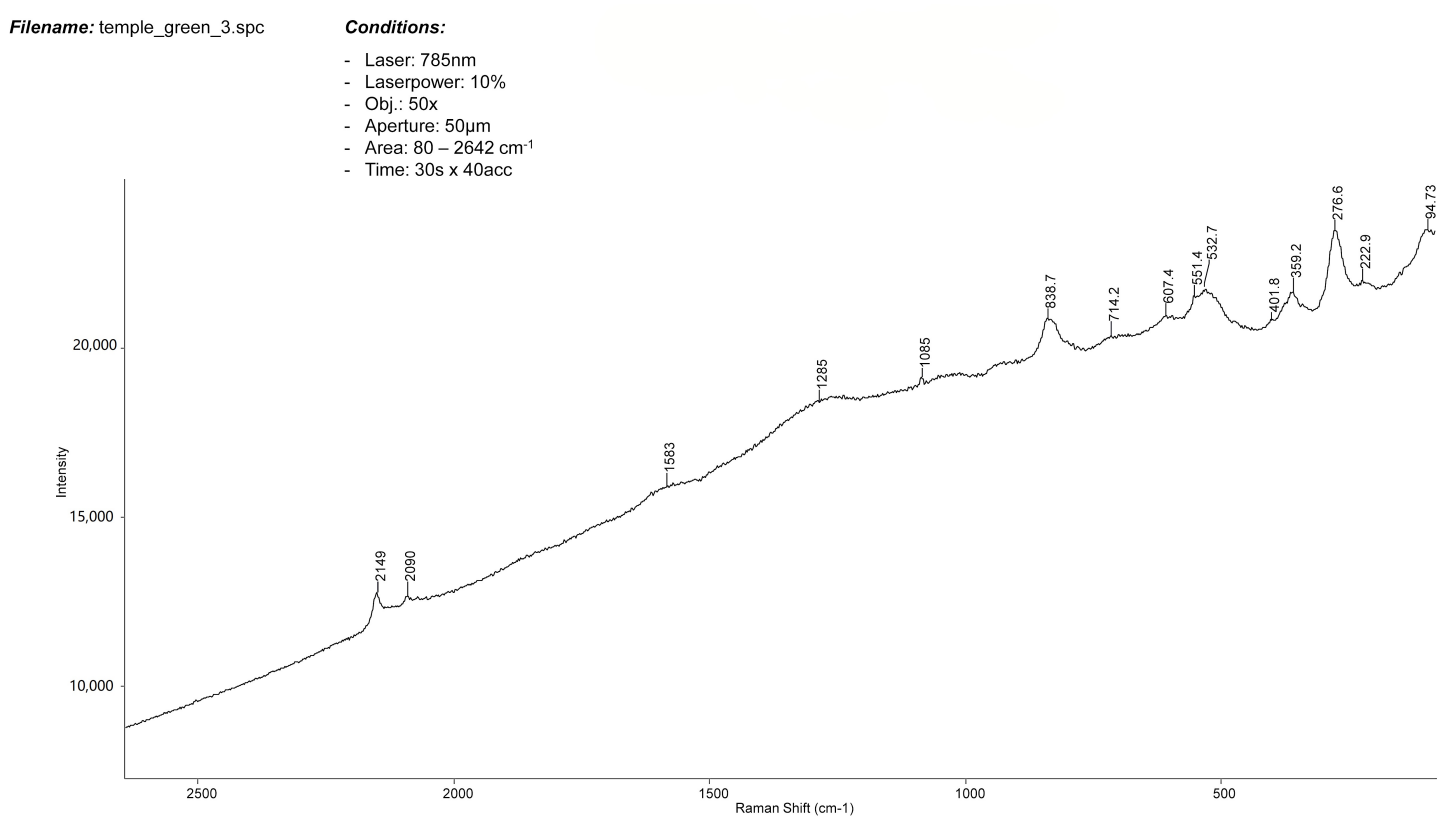

Figure 6. Raman spectrum of dark green pigment, $785 \mathrm{~nm}$ excitation, showing Prussian blue, chrome yellow, calcite, and carbon black.

Black: bone black, with evidence of a phosphate signature (Figure 7).

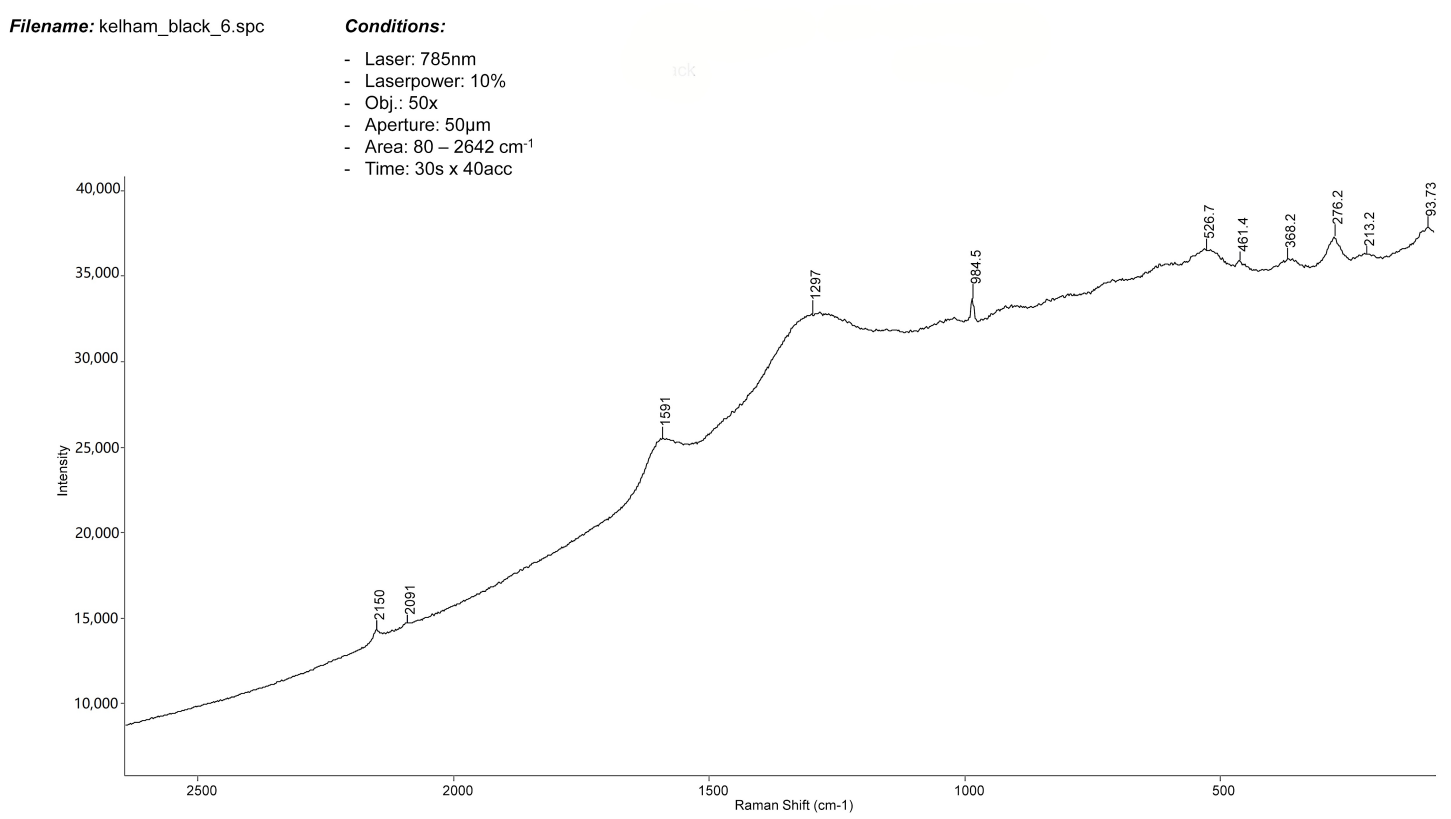

Figure 7. Raman spectrum of black pigment, $785 \mathrm{~nm}$ excitation, showing bone black.

Cream: gypsum, calcite, and barytes (Figure 8). 


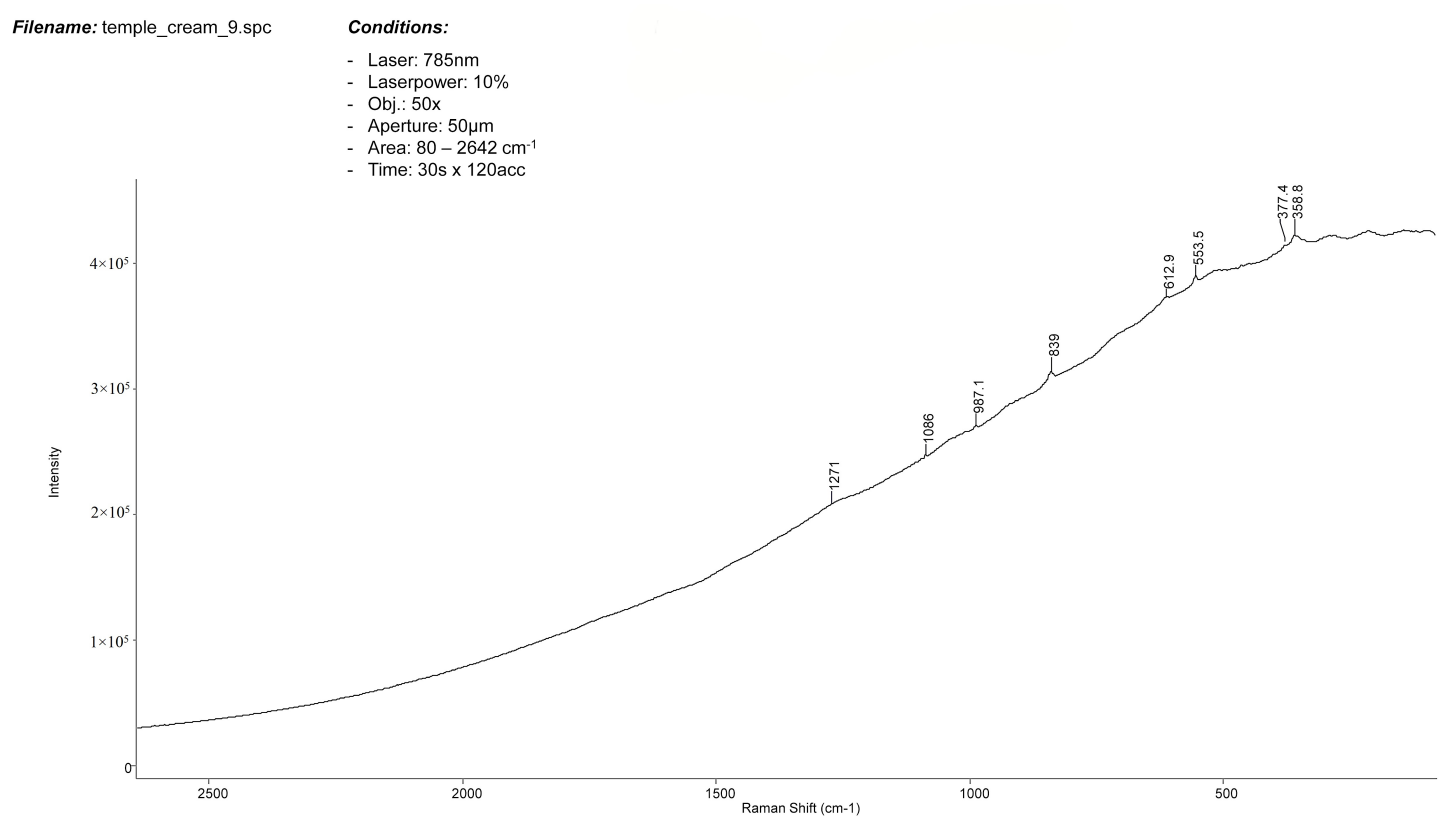

Figure 8. Raman spectrum of cream pigment, $785 \mathrm{~nm}$ excitation, showing calcite and barytes.

Light green: Prussian blue, chrome yellow, and gypsum (Figure 9).

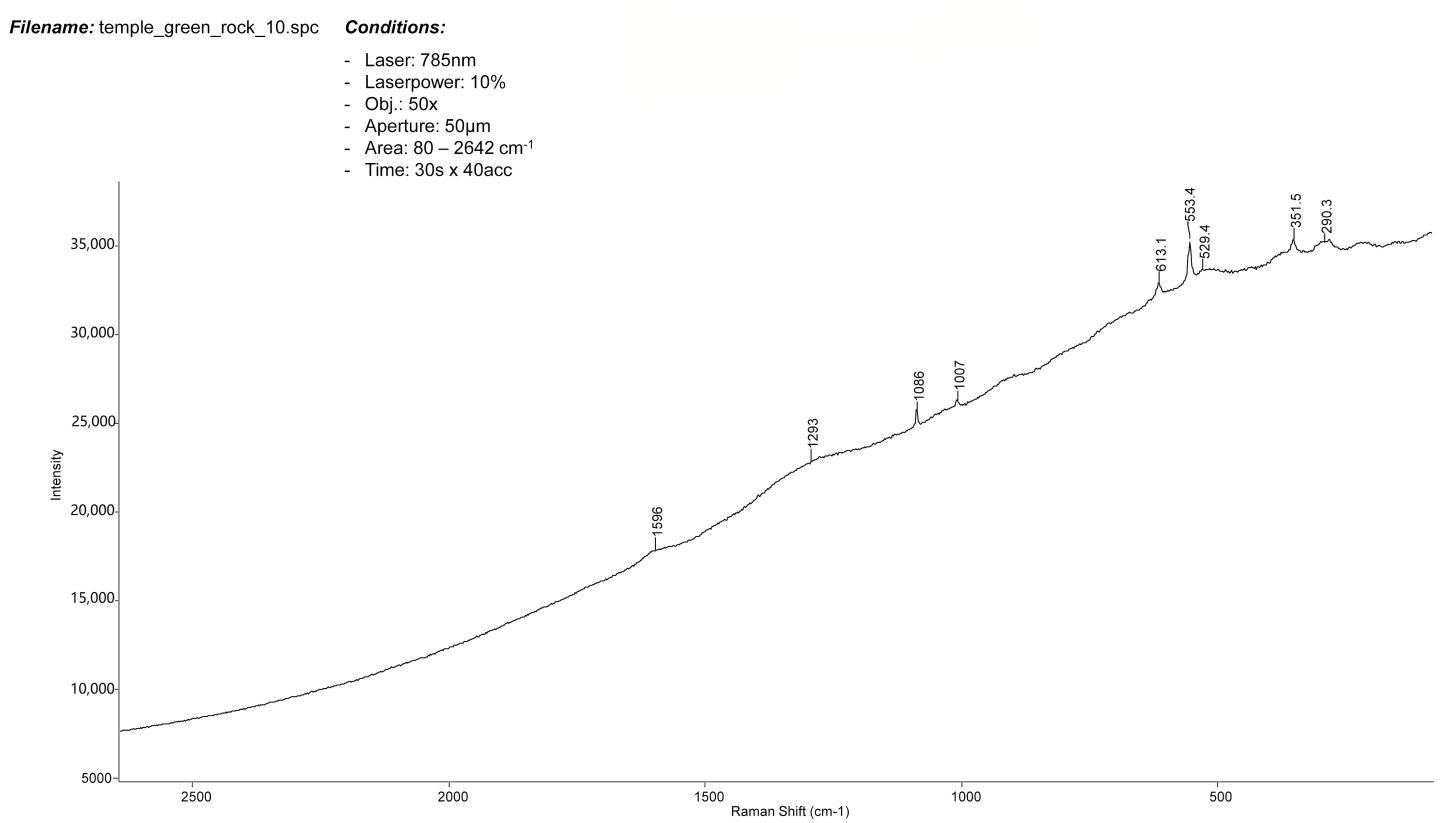

Figure 9. Raman spectrum of light green pigment, $785 \mathrm{~nm}$ excitation, showing Prussian blue, chrome yellow, and gypsum.

The red pigments, red lead, and hematite were used in admixture to achieve different tonal qualities and the addition of chrome yellow would give an orange colouration. Lightening was achieved using a mixture of calcite and gypsum. The blue colour was exclusively Prussian blue with the addition of calcite and calcium sulfate for lightening. The specific usage of anhydrite here could be indicative of an additional purpose such as adhesion. A purple colour involved a mixture of Prussian blue and hematite with carbon black added to darken the colour but this colour is not evident to the eye in the scheme and samples probably represent adulterated blue pigment. The green colour, a combination of yellow and blue, involved the admixture of Prussian blue and chrome yellow, with both calcite and carbon black being present to give darker and lighter shades. The black colour 
is interesting in that it contains the phosphate band signature of calcium phosphate which reveals that it is really ivory black or bone black, made by the calcination of animal bones or ivory at low temperatures: higher temperatures of calcination burns off the carbon to leave bone white, a calcium apatite [49]. Several prominent artists in the nineteenth century preferred bone black or ivory black for their work as the black colour is glossier than the normal charcoal black or soot: for example John Constable was a user of ivory black $[50,51]$. The cream colour is a rather complex mixture of calcite, gypsum, and barytes which is an interesting departure from the normal use of lead-based whites; it has been observed that the use of calcite enhances both the optical and the rheological properties of the colour and yields a creamish, translucent effect owing to its refractive index when ground in an oil medium [52]. Finally, the light green colour was effected using a mixture of Prussian blue, chrome yellow, and gypsum.

\section{Discussion}

This is the first known time that an analytical assessment of the pigments and palette of Temple Moore has been undertaken and it reveals that he showed favour for Prussian blue, chrome yellow, red lead, hematite, and carbon black as his strong colours. Dilution and lightening or darkening effects were promoted using calcite, gypsum, and occasionally anhydrite and barytes. The use of anhydrite and barytes only occasionally indicates that perhaps there were some special reasons for their inclusion in the pigment mixtures at those locations, possibly to combat a dark or uncompromising substrate. The red specimen is interesting in that it is the only one that shows evidence of an organic additive, which could be either a varnish or an adhesive binder, such as, typically, a pine resin. Likewise remarkable are the absence of other strong pigments from his palette and favoured by many of his contemporaries [53,54] such as ultramarine, basic lead white (hydrocerussite), orpiment, azurite, malachite, and weaker but more common ones such as goethite and verdigris. The admixture of red lead and hematite in the red pigment is also rather curious and was intended obviously for a particular tonal shade. Unusual admixture for red paint has been observed previously in one of Sir Ninian Comper's schemes only ten years earlier [55].

Clearly the choice of pigments was limited by those commercially available in 1906-1907, and the purchase of these would have been the responsibility of the decorative artist, John Thomas. It seems logical that Thomas would have selected his range from a large, well respected company such as Winsor and Newton, Henry Nathan \& Sons, or Reeves and Sons Ltd., and trade catalogues survive from the period [56]. Prussian blue, chrome yellow, lamp black, and ivory black, were all available as oil-based media in collapsible tubes from Winsor and Newton at the trade price of 3s. 0d. (British) per dozen in 1900; this equates to a very approximate cost of $£ 12$ sterling in a contemporary context and is at the lower end of the cost scale in the full range of pigments offered. The aromatic resin observed in the analysis of the red pigment may possibly be Sandarac [57], an aromatic, translucent resin used to impart a warm, reddish tone, or else the commonly used Dammar resin [58]; alternatively it may have been added as a form of drying oil. The presence of hematite may perhaps be ascribed to the use of Cassel earth or Cologne earth, both also purchasable. However, the use of earth pigments such as calcite for the whites and creams is more unusual and Thomas may have been aiming for a specific tonal effect rather than trying to save on cost, e.g., by using these low-cost pigments as extenders [59]. Alternatively Moore and Thomas may well have been aware of the toxicity of lead-based pigments (on an organ case that would be subject to regular handling) and/or the risks of degradation of synthetic additions [60] and thus preferred to use a simple, earth pigment. The availability of these pigments throughout history has been commonplace [61], therefore it would have been an easy pigment to obtain. A final possibility is that Moore and Thomas were aware that adding lead white or titanium white to Prussian blue yielded problems with the lightfastness and permanence of the admixture and so chose calcite instead [62].

In conclusion, the analysis has revealed that the decorative artist, John Thomas, appears to have chosen readily available pigments based on broad colour instructions from Temple Moore to achieve 
his design. The analysis of further decorative artwork by this architect will be of considerable interest where he used different named decorative artists, but similar designs, to reveal what similarities or differences occur in pigment composition.

Author Contributions: Conceptualization, C.B. and M.P.; methodology, C.B., H.E., P.V., S.L., and M.P.; software, P.V. and S.L.; validation, C.B., H.E., P.V., S.L., and M.P.; formal analysis, H.E.; investigation, C.B., H.E., P.V., S.L., and M.P.; resources, P.V. and M.P.; data curation, C.B., H.E., and P.V.; writing-original draft preparation, C.B.; writing-review and editing, H.E., P.V., and M.P.; visualization, P.V. and S.L. All authors have read and agreed to the published version of the manuscript.

Funding: This research received no external funding.

Acknowledgments: The authors are extremely grateful to the extensive help offered by Martin Cooper, who procured the organ case and project-managed its installation and restoration, in addition to undertaking background historic research. We are also grateful to the Parochial Church Council of Kelham St Wilfrid's church for permission to undertake this analysis. Geoff Brandwood has been exceptionally helpful in providing important background, historical information and to him we owe our sincere thanks. The authors also appreciate input given by Clare Hartwell on period British architects.

Conflicts of Interest: The authors declare no conflict of interest.

\section{References}

1. Brandwood, G. The Architecture of Temple Moore; Shaun Tyas: Donington, UK, 2019; ISBN 978-1-907730-75-7.

2. Pevsner, N.; Harris, J.; Antram, N. Lincolnshire; Yale University Press: New Haven, CT, USA; London, UK, 2002; ISBN 978-0-300-09620-0.

3. Hill, A.G. The Organ-Cases and Organs of the Middle Ages and Renaissance: A Comprehensive Essay on the Art and Archaeology of the Organ; David Bogue: London, UK, 1883.

4. Moore, T.L. Accounts Book, 1891-1907; RIBA Library Archive MOT2/3: London, UK, 1907.

5. Southwell and Nottingham Church History Project: Kelham St Wilfrid. Available online: https: //southwellchurches.nottingham.ac.uk/kelham/horgan.php (accessed on 18 September 2020).

6. Bianchi-Bosisio, A. PROTEINS | Physiological Samples. In Encyclopedia of Analytical Science; Elsevier: Amsterdam, The Netherlands, 2005; pp. 357-375. ISBN 978-0-12-369397-6.

7. Ghezzi, L.; Duce, C.; Bernazzani, L.; Bramanti, E.; Colombini, M.P.; Tiné, M.R.; Bonaduce, I. Interactions between inorganic pigments and rabbit skin glue in reference paint reconstructions. J. Therm. Anal. Calorim. 2015, 122, 315-322. [CrossRef]

8. Petrova, O.; Pankin, D.; Povolotckaia, A.; Borisov, E.; Krivul'ko, T.; Kurganov, N.; Kurochkin, A. Pigment palette study of the XIX century plafond painting by Raman spectroscopy. J. Cult. Herit. 2019, 37, 233-237. [CrossRef]

9. VanSnick, S.; Fleming, N. Re-housing and a preliminary evaluation of conservation treatment methods for scraperboard artworks. J. Inst. Conserv. 2011, 34, 145-158. [CrossRef]

10. Anon. Architectural Notes. Musical Stand. 1869, 11, 197-198.

11. Brandwood, G.K. Temple Moore: An Architect of the Late Gothic Revival; Paul Watkins Publishing: Stamford, UK, 1997; ISBN 978-1-900289-03-0.

12. Curl, J.S. Victorian Architecture: Diversity Invention; Spire Books: Reading, UK, 2007; ISBN 978-1-904965-06-0.

13. Powell, K. Polychromatic Splendour: The Great Victorian Churches of London. Ctry. Life 1986, 180, $26-29$.

14. Deneckere, A.; Hocquet, F.-P.; Born, A.; Klein, P.; Rakkaa, S.; Lycke, S.; De Langhe, K.; Martens, M.P.J.; Strivay, D.; Vandenabeele, P.; et al. Direct analysis of the central panel of the so-called Wyts triptych after Jan van Eyck: Direct analysis of the central panel of the so-called Wyts triptych. J. Raman Spectrosc. 2010, 41, 1500-1509. [CrossRef]

15. Berrie, B.H. Rethinking the History of Artists' Pigments through Chemical Analysis. Annu. Rev. Anal. Chem. 2012, 5, 441-459. [CrossRef]

16. Howard, H. Pigments of English Medieval Wall Painting; Archetype: London, UK, 2003; ISBN 978-1-873132-48-7.

17. Vornicu, N.; Bibire, C.; Murariu, E.; Ivanov, D. Analysis of mural paintings using in situ non-invasive XRF, FTIR spectroscopy and optical microscopy: Analysis of mural paintings using in situ non-invasive XRF portable. X-Ray Spectrom. 2013, 42, 380-387. [CrossRef] 
18. Fikri, I.; El Amraoui, M.; Haddad, M.; Ettahiri, A.S.; Bellot-Gurlet, L.; Falguères, C.; Lebon, M.; Nespoulet, R.; Ait Lyazidi, S.; Bejjit, L. XRF and UV-Vis-NIR analyses of medieval wall paintings of al-Qarawiyyin Mosque (Morocco). IOP Conf. Ser. Mater. Sci. Eng. 2018, 353, 012020. [CrossRef]

19. Symondson, A.; Bucknall, S.A.; Comper, N. Sir Ninian Comper: An Introduction to His Life and Work with Complete Gazetteer; Spire Books; Ecclesiological Society: Reading, UK, 2006; ISBN 978-1-904965-11-4.

20. Howell, P. “Our very quaint old architect": Some Letters of William Butterfield. Archit. Hist. 2010, 53, 217-243. [CrossRef]

21. Hall, M. George Frederick Bodley and the Later Gothic Revival in Britain and America; Yale University Press: New Haven, CT, USA, 2014; ISBN 978-0-300-20802-3.

22. Crook, J.M. William Burges and the High Victorian Dream; Frances Lincoln: London, UK, 2013; ISBN 978-0-7112-3349-2.

23. Gradidge, R. Edwin Lutyens: Architect Laureate; Allen \& Unwin: London, UK; Boston, MA, USA, 1981; ISBN 978-0-04-720023-6.

24. Smith, G.D.; Clark, R.J.H. Raman microscopy in art history and conservation science. Stud. Conserv. 2001, 46, 92-106. [CrossRef]

25. Parisi, C.; Pelosi, C.; Santamaria, U.; Pogliani, P.; Agresti, G.; Longo, S. The Conservation Project of a Liturgical Object: The Case of Infant Jesus of Prague in the Church of Saint Mary of Providence at Macchia Giarre (Italy). Eur. J. Sci. Theol. 2016, 12, 235-244.

26. Giustetto, R.; Moschella, E.M.; Cristellotti, M.; Costa, E. Deterioration of building materials and artworks in the 'Santa Maria della Stella' church, Saluzzo (Italy): Causes of decay and possible remedies. Stud. Conserv. 2017, 62, 474-493. [CrossRef]

27. Vandenabeele, P. Practical Raman Spectroscopy-An Introduction: Vandenabeele/Practical Raman Spectroscopy - An Introduction; John Wiley \& Sons, Ltd.: Chichester, UK, 2013; ISBN 978-1-119-96128-4.

28. Edwards, H.G.M. Historical Pigments: A Survey of Analytical Chemical Archaeometric Usage and Terminology for Forensic Art Analysis. In Encyclopedia of Analytical Chemistry; Meyers, R.A., Ed.; John Wiley \& Sons, Ltd.: Chichester, UK, 2015; pp. 1-12. ISBN 978-0-470-02731-8.

29. Petrova, O.I.; Pankin, D.V.; Povolotckaia, A.V.; Borisov, E.V.; Beznosova, M.O.; Krivul'ko, T.A.; Kurochkin, A.V. Identification of Pigments in Colored Layers of a Painting by Raman Spectroscopy. Opt. Spectrosc. 2017, 123, 965-969. [CrossRef]

30. Edwards, H.G.M.; Chalmers, J.M. Raman Spectroscopy in Archaeology and Art History; Royal Society of Chemistry: Cambridge, UK, 2018; ISBN 978-1-78801-138-9.

31. De Mendes, I.C.; Santos Oliveira, J.A.; Dantas, M.S.S. Characterization of 20th century art materials from the Lasar Segall Museum. J. Raman Spectrosc. 2018, jrs.5530. [CrossRef]

32. Giorgi, L.; Nevin, A.; Nodari, L.; Comelli, D.; Alberti, R.; Gironda, M.; Mosca, S.; Zendri, E.; Piccolo, M.; Izzo, F.C. In-situ technical study of modern paintings part 1: The evolution of artistic materials and painting techniques in ten paintings from 1889 to 1940 by Alessandro Milesi (1856-1945). Spectrochim. Acta Part A Mol. Biomol. Spectrosc. 2019, 219, 530-538. [CrossRef]

33. Lluveras-Tenorio, A.; Spepi, A.; Pieraccioni, M.; Legnaioli, S.; Lorenzetti, G.; Palleschi, V.; Vendrell, M.; Colombini, M.P.; Tinè, M.R.; Duce, C.; et al. A multi-analytical characterization of artists' carbon-based black pigments. J. Therm. Anal. Calorim. 2019, 138, 3287-3299. [CrossRef]

34. Arjonilla, P.; Ayora-Cañada, M.J.; Rubio Domene, R.; Correa Gómez, E.; de la Torre-López, M.J.; Domínguez-Vidal, A. Romantic restorations in the Alhambra monument: Spectroscopic characterization of decorative plasterwork in the Royal Baths of Comares. J. Raman Spectrosc. 2019, 50, 184-192. [CrossRef]

35. Edwards, H.G.M.; Farwell, D.W.; Brooke, C.J. Raman spectroscopic study of a post-medieval wall painting in need of conservation. Anal. Bioanal. Chem. 2005, 383, 312-321. [CrossRef]

36. Gabrieli, F.; Doherty, B.; Miliani, C.; Degano, I.; Modugno, F.; Uldank, D.; Kunzelman, D.; Buzzegoli, E.; Patti, M.; Rosi, F. Micro-Raman and SER spectroscopy to unfold Lefranc's early organic pigment formulations: Micro-Raman and SER spectroscopy. J. Raman Spectrosc. 2016, 47, 1505-1513. [CrossRef]

37. Candeias, A.; Madariaga, J.M. Applications of Raman spectroscopy in art and archaeology. J. Raman Spectrosc. 2019, jrs.5571. [CrossRef]

38. Clark, R.J.H. Raman microscopy: Application to the identification of pigments on medieval manuscripts. Chem. Soc. Rev. 1995, 24, 187. [CrossRef] 
39. Bell, I.M.; Clark, R.J.H.; Gibbs, P.J. Raman spectroscopic library of natural and synthetic pigments (pre- $\approx 1850$ AD). Spectrochim. Acta Part A Mol. Biomol. Spectrosc. 1997, 53, 2159-2179. [CrossRef]

40. Derbyshire, A.; Withnall, R. Pigment analysis of portrait miniatures using Raman microscopy. J. Raman Spectrosc. 1999, 30, 185-188. [CrossRef]

41. Burgio, L.; Clark, R.J.H. Library of FT-Raman spectra of pigments, minerals, pigment media and varnishes, and supplement to existing library of Raman spectra of pigments with visible excitation. Spectrochim. Acta Part A Mol. Biomol. Spectrosc. 2001, 57, 1491-1521. [CrossRef]

42. Brown, K.L.; Clark, R.J.H. Three English manuscripts post-1066AD: Pigment identification and palette comparisons by Raman microscopy. J. Raman Spectrosc. 2004, 35, 217-223. [CrossRef]

43. Bouchard, M.; Smith, D.C. Database of 74 Raman spectra of standard minerals of relevance to metal corrosion, stained glass or prehistoric rock art. In Raman Spectroscopy in Archaeology and Art History; Royal Society of Chemistry: Cambridge, UK, 2005; pp. 429-464.

44. García-Bucio, M.A.; Casanova-González, E.; Ruvalcaba-Sil, J.L.; Arroyo-Lemus, E.; Mitrani-Viggiano, A. Spectroscopic characterization of sixteenth century panel painting references using Raman, surface-enhanced Raman spectroscopy and helium-Raman system for in situ analysis of Ibero-American Colonial paintings. Phil. Trans. R. Soc. A. 2016, 374, 20160051. [CrossRef]

45. Ciliberto, E.; Spoto, G. Modern Analytical Methods in Art and Archaeology; Wiley: New York, NY, USA, 2000; ISBN 978-0-471-29361-3.

46. Edwards, H.G.M. Raman spectroscopy at longer excitation wavelengths applied to the forensic analysis of archaeological specimens: A novel aspect of forensic geoscience. In Infrared and Raman Spectroscopy in Forensic Science; Chalmers, J.M., Edwards, H.G.M., Hargreaves, M.D., Eds.; John Wiley \& Sons, Ltd.: Chichester, UK, 2012; pp. 481-511. ISBN 978-1-119-96232-8.

47. Carter, E.A. Biological materials of significance to cultural heritage. In Raman Spectroscopy in Archaeology and Art History; Royal Society of Chemistry Publishing: Cambridge, UK, 2018; pp. 97-122.

48. Chaplin, T.D.; Clark, R.J.H.; Jones, R.; Gibbs, R. Pigment analysis by Raman microscopy and portable X-ray fluorescence ( $\mathrm{pXRF}$ ) of thirteenth to fourteenth century illuminations and cuttings from Bologna. Phil. Trans. R. Soc. A. 2016, 374, 20160043. [CrossRef]

49. Eastaugh, N. The Pigment Compendium: A Dictionary of Historical Pigments; Elsevier Butterworth-Heinemann: Amsterdam, The Netherlands; Boston, MA, USA, 2004; ISBN 978-0-08-047376-5.

50. Parris, L.; Fleming-Williams, I. Constable; Tate Gallery: London, UK, 1991; ISBN 978-1-85437-070-9.

51. Duff, N. Constable's Sketch for Hadleigh Castle: A Technical Examination. Tate Pap. 2006, 5, 1-8.

52. De Viguerie, L.; Glanville, H.; Ducouret, G.; Jacquemot, P.; Dang, P.A.; Walter, P. Re-interpretation of the Old Masters' practices through optical and rheological investigation: The presence of calcite. Comptes Rendus Phys. 2018, 19, 543-552. [CrossRef]

53. Favaro, M.; Bianchin, S.; Vigato, P.A.; Vervat, M. The palette of the Macchia Italian artist Giovanni Fattori in the second half of the xixth century. J. Cult. Herit. 2010, 11, 265-278. [CrossRef]

54. Christiansen, M.B.; Baadsgaard, E.; Sanyova, J.; Simonsen, K.P. The artists' materials of P. S. Krøyer: An analytical study of the artist's paintings and tube colours by Raman, SEM-EDS and HPLC. Herit. Sci. 2017, 5, 39. [CrossRef]

55. Edwards, H.G.M.; Wolstenholme, R.; Wilkinson, D.S.; Brooke, C.; Pepper, M. Raman spectroscopic analysis of the enigmatic Comper pigments. Anal. Bioanal. Chem. 2007, 387, 2255-2262. [CrossRef] [PubMed]

56. Trade Catalogue Winsor \& Newton Limited Manufacturing Artists' Colourmen; Winsor \& Newton: London, UK, 1900.

57. Silverman, C.; Rizzo, A.; Carò, F. An investigation of eighteenth-century English red japanned furniture in the collection of the metropolitan museum of art, New York. Stud. Conserv. 2019, 64, S126-S138. [CrossRef]

58. Standeven, H.A.L. Oil-Based House Paints from 1900 to 1960: An Examination of Their History and Development, with Particular Reference to Ripolin Enamels. J. Am. Inst. Conserv. 2013, 52, 127-139. [CrossRef]

59. Townsend, J.H.; Carlyle, L.; Khandekar, N.; Woodcock, S. Later nineteenth century pigments: Evidence for additions and substitutions. Conserv. 1995, 19, 65-78. [CrossRef]

60. Van Driel, B.A.; van den Berg, K.J.; Gerretzen, J.; Dik, J. The white of the 20th century: An explorative survey into Dutch modern art collections. Herit. Sci. 2018, 6, 16. [CrossRef] 
61. Gettens, R.J.; Fitzhugh, E.W.; Feller, R.L. Calcium Carbonate Whites. Stud. Conserv. 1974, 19, 157-184. [CrossRef]

62. Kirby, J.; Saunders, D. Fading and Colour Change of Prussian Blue: Methods of Manufacture and the Influence of Extenders. Natl. Gallery Tech. Bull. 2004, 25, 73-99.

Publisher's Note: MDPI stays neutral with regard to jurisdictional claims in published maps and institutional affiliations.

(C) 2020 by the authors. Licensee MDPI, Basel, Switzerland. This article is an open access article distributed under the terms and conditions of the Creative Commons Attribution (CC BY) license (http://creativecommons.org/licenses/by/4.0/). 